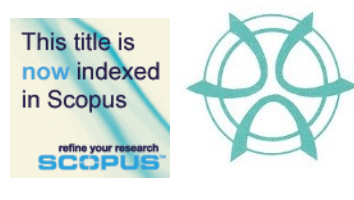

PLANNING MALAYSIA:

Journal of the Malaysian Institute of Planners

VOLUME 18 ISSUE 1 (2020), Page 35 - 44

\title{
THE IMPACT OF PERSONALITY AND LIFESTYLE ON INTERACTION WITH NATURE
}

\author{
Aisyah Abu Bakar ${ }^{1}$, Mariana Mohamed Osman² \& Mizan Hitam³ \\ ${ }^{1,2}$ Kulliyyah of Architecture and Environmental Design \\ INTERNATIONAL ISLAMIC UNIVERSITY MALAYSIA \\ ${ }^{3}$ Faculty of Architecture, Panning and Surveying \\ UNIVERSITI TEKNOLOGI MARA
}

\begin{abstract}
Awareness on the complex interdepending systems between individuals and their contexts is a fundamental understanding of sustainable well-being. Collectivist beliefs and biospheric values translate the normative behaviours when environmental decisions are being made. Issue: Existing research has limited empirical evidence on the impact of personality and lifestyle (PL) on interaction with nature (IN) for Malaysia. Purpose: This paper aims to verify the statistical predictability of IN based on PL. Approach: Multiple Correlation and Multiple Linear Regression were carried out to assess linear associations and parameters of linear equations to predict IN components based on PL items. Findings: IN components were predictable by the majority of the PL items and 'feeling affected by the environmental loss of other countries' was the strongest predictor of IN.
\end{abstract}

Keyword: interaction with nature, personality and lifestyle 
Mariana Mohamed Osman, Farah Eleena Zainudin, Noor Suzilawati Rabe, Mizan Hitam \& Muhammad Faris Abdullah

An Assessment of Housing Affordability Index at Districts Level in Kelantan

\section{INTRODUCTION}

Human interdependence with the environment (HIE) is one of the strong sources of subjective sustainable well-being (SSWB). Personality and lifestyle (PL) and interaction with nature (IN) are dimensions of HIE that mutually stimulate one another (Abu Bakar et al., 2017a, 2017b, 2017c, 2018). Human beings willingly influence their surroundings directly and indirectly. The direct influence is often demonstrated in the willingness to assist each other in pursuing worthy life goals by helping and nurturing others and being good role models. The indirect influence is revealed in contagious emotions, empathic resonance and imitation of empathy towards the surrounding environment. This paper assesses the statistical predictability of IN based on PL.

\section{LITERATURE REVIEW}

Case studies based on articles from selected Asian Journals from the year 2011 onwards highlight conditional factors and potential determinants of Interaction with Nature (IN). Table 1 summarizes these findings.

Table 1 Conditional Factors and Potential Determinants for Interaction with Nature

\begin{tabular}{|c|c|c|}
\hline Conditional Factors & Potential Determinants & References \\
\hline $\begin{array}{l}\text { Unmaintained outdoor space: murky water that } \\
\text { provides a place for mosquito breeding, too dense } \\
\text { vegetation, and tall and bushy that blocked views. }\end{array}$ & $\begin{array}{l}\text { Emotions and feelings } \\
\text { (safety and security) } \\
\text { induced in natural elements }\end{array}$ & uthaveeran, \\
\hline $\begin{array}{l}\text { Motivation (to experience nature, to unwind) activities } \\
\text { (appreciating nature, trekking and hill climbing, } \\
\text { observing sunrise, observing hilltop scenery,). }\end{array}$ & $\begin{array}{l}\text { The urge to be in nature, } \\
\text { knowledge and ability to } \\
\text { cope with outdoors. }\end{array}$ & ol et al., \\
\hline $\begin{array}{l}\text { gended on a variety of park elements, } \\
\text { gn of the park, distance to the park, } \\
\text { park, and active areas in the park }\end{array}$ & $\begin{array}{l}\text { The inclination to be close to } \\
\text { natural or outdoor areas, the } \\
\text { urge to spend time in the } \\
\text { outdoor environment }\end{array}$ & kur et al., \\
\hline $\begin{array}{l}\text { Health condition and availability of natural } \\
\text { environmental, views and accessibility to outdoors }\end{array}$ & & $\begin{array}{ll}\text { li } & \& \\
2011) & \\
\end{array}$ \\
\hline $\begin{array}{l}\text { nitive well- } \\
\text { sense of }\end{array}$ & $\begin{array}{l}\text { sant experience } \\
\text { tting: relaxed, } \\
\text { healthy }\end{array}$ & asor et al., \\
\hline correspond with & $\begin{array}{l}\mathrm{He} \\
\text { ou }\end{array}$ & dee et al., \\
\hline $\begin{array}{l}\text { on of natural elements to encourage } \\
\text { on (sense of connectedness to greeneries and } \\
y \text { of spaces and diversity of natural elements) }\end{array}$ & $\begin{array}{l}\text { osity and } \\
\text { creative } \\
\text { ral setting }\end{array}$ & $\begin{array}{l}\text { (Faizi et al., } \\
2013)\end{array}$ \\
\hline $\begin{array}{l}\text { Age } \\
\text { issu }\end{array}$ & $\begin{array}{l}\text { l he } \\
\text { ity in ou }\end{array}$ & et al., \\
\hline $\begin{array}{l}\text { The } \\
\text { grou }\end{array}$ & st to & san et al., \\
\hline ural features and distinct character of & details) & $\begin{array}{l}\text { (Mahidin \& } \\
\text { Maulan, 2012) }\end{array}$ \\
\hline
\end{tabular}

The findings from the case studies generate three significant components of IN: (i) Nature Attachment (INa), (ii) Knowledge and Capability (INb) and (iii) Inclination towards Nature (INc). 
Table 2 Components and Determinants of Interaction with Nature

\begin{tabular}{|c|c|c|c|}
\hline Definition of IN & Components & Indicators & Code \\
\hline \multirow{10}{*}{$\begin{array}{l}\text { The internal and } \\
\text { external emotions } \\
\text { and aptitudes } \\
\text { towards the } \\
\text { natural } \\
\text { environment } \\
\text { expressed in the } \\
\text { contact between } \\
\text { human and the } \\
\text { ecological nature }\end{array}$} & \multirow{2}{*}{$\begin{array}{c}\text { Nature } \\
\text { Attachment }\end{array}$} & outdoor environment determining own health and wellness & \multirow{2}{*}{$\mathrm{INa}$} \\
\hline & & being able to recall experiences in the natural environment & \\
\hline & \multirow{4}{*}{$\begin{array}{c}\text { Knowledge } \\
\text { and } \\
\text { Capability }\end{array}$} & being able to adapt to various outdoor surroundings & \multirow{4}{*}{$\mathrm{INb}$} \\
\hline & & being able to see and hear what others usually miss in nature & \\
\hline & & being able to notice scientific details of nature & \\
\hline & & being able to cope with the outdoor environment & \\
\hline & \multirow{4}{*}{$\begin{array}{c}\text { Inclination } \\
\text { towards } \\
\text { Nature }\end{array}$} & feeling the urge to spend time in the natural environment & \multirow{4}{*}{$\mathrm{INc}$} \\
\hline & & tending to lose concentration without contact with nature & \\
\hline & & tending to have objects from the outdoors in personal space & \\
\hline & & spending time planting at home & \\
\hline
\end{tabular}

Personal Lifestyle (PL) manifests in the personal outlook and approach to life in relation to environmental consciousness (Abu Bakar et al., 2017a, $2017 b, 2017 \mathrm{c}, 2018$ ). Qualities adhere to PL include (i) moral stance in collectivistic values (Laurens, 2012; Clark et al., 2014; Caesar, 2016), (ii) commitment to modest and environmental choices (Horayangkura, 2012; Laurens, 2012; Khare, 2015; Ming et al., 2015), and (iii) environmental concerns through knowledge and awareness (Horayangkura, 2012; Ming et al., 2015).

Table 3 Determinants of Personal Lifestyle

\begin{tabular}{|c|c|c|}
\hline Definition of PL & Indicators & Code \\
\hline \multirow{10}{*}{$\begin{array}{l}\text { The personal orientation that } \\
\text { portrays collectivistic } \\
\text { worldviews, modesty and } \\
\text { humility towards others as well as } \\
\text { consciousness of environmental } \\
\text { issues }\end{array}$} & favouring relationships with others over personal success & PL1 \\
\hline & choosing to disappointing self over disappointing family & PL2 \\
\hline & taking account others' opinions in making life decisions & PL3 \\
\hline & taking the pleasure of working with others & PL4 \\
\hline & practising moderation in purchasing and using resources & PL5 \\
\hline & feeling unconcerned if not being able to afford things & PL6 \\
\hline & believing that having many assets does not lead to happiness & PL7 \\
\hline & being mindful about environmental destruction & PL8 \\
\hline & feeling affected by the environmental loss of other countries & PL9 \\
\hline & urging media to raise more environmental awareness & PL10 \\
\hline
\end{tabular}

According to theoretical fundamentals, the research hypothesizes that IN components are predictable by PL. The following sections provide empirical evidence on the predictability of $\mathrm{INa}, \mathrm{INb}$ and $\mathrm{INc}$ based on PL items.

\section{METHOD}

A sample of 4315 was pooled and analyzed. An 11-point Likert scale was given to the Malaysian respondents to reply to questionnaire items which include the components of IN and the ten (10) PL items. Pearson correlation analyses were carried out to determine significant linear associations between the IN components and PL items. After the correlation analyses, multiple linear regression analyses were executed to estimate parameters of the linear equations in order to predict values of INa, INb and INc from PL items. 
Aisyah Abu Bakar, Mariana Mohamed Osman \& Mizan Hitam

The Impact of Personality and Lifestyle on Interaction with Nature

\section{RESULTS AND DISCUSSION}

Table 4 Multiple Correlations between PL items and INa, INb and INc

\begin{tabular}{|c|c|c|c|c|c|c|c|c|c|c|c|}
\hline & $\mathrm{H}_{0}$ & \multicolumn{10}{|c|}{ There is no statistically significant correlation between INa and respective PL items } \\
\hline & $\mathrm{H}_{0}$ & \multicolumn{10}{|c|}{ There is no statistically significant correlation between INb and respective PL items } \\
\hline & $\mathrm{H}_{0}$ & \multicolumn{10}{|c|}{ There is no statistically significant correlation between INc and respective PL items } \\
\hline \multicolumn{12}{|c|}{ Correlation Strength Threshold (Dancey \& Riley, 2004) } \\
\hline 0 & .1 & .2 & & 3 & 4 & 5 & .6 & .7 & 8 & 9 & 1 \\
\hline zero & \multicolumn{4}{|c|}{ weak } & \multicolumn{3}{|c|}{ moderate } & \multicolumn{3}{|c|}{ strong } & rfect \\
\hline DV & Stats & PL1 & PL2 & PL3 & PL4 & PL5 & PL6 & PL7 & PL8 & PL9 & PL10 \\
\hline \multirow{3}{*}{$\mathrm{INa}$} & r & $360^{* *}$ & $345^{* *}$ & $356^{* *}$ & $.401^{* *}$ & .35 & $292^{* *}$ & $.293^{* *}$ & $347^{* *}$ & $.365^{* *}$ & $394^{* *}$ \\
\hline & $\mathrm{p}$ & .0 & & .00 & & & & .000 & - & .000 & 0 \\
\hline & $\mathrm{N}$ & & & 4315 & & & 4315 & 315 & & 4315 & 15 \\
\hline \multirow{3}{*}{$\mathrm{INb}$} & $\mathrm{r}$ & $.321^{* *}$ & $.325^{* *}$ & $.343^{* *}$ & $366^{* *}$ & $.349^{* *}$ & $.314^{* *}$ & $.323^{* *}$ & $.372^{* *}$ & $.357^{* *}$ & $337^{* *}$ \\
\hline & $\mathrm{p}$ & .000 & & .000 & .000 & & .000 & .000 & .000 & .000 & .000 \\
\hline & $\mathrm{N}$ & 5 & 43 & 4315 & 4315 & 4315 & 4315 & 4315 & 4315 & 4315 & 4315 \\
\hline \multirow{3}{*}{ INc } & $\mathrm{r}$ & $.273^{* *}$ & $268^{* *}$ & $298^{* *}$ & $.323^{* *}$ & $.321^{* *}$ & $297^{* *}$ & $.312^{* *}$ & $342^{* *}$ & $.326^{* *}$ & $318^{* *}$ \\
\hline & $p$ & .000 & & .000 & .000 & .000 & .000 & .000 & .000 & $\begin{array}{l}.000 \\
\end{array}$ & .000 \\
\hline & $\mathrm{N}$ & 4315 & 4315 & 4315 & 4315 & 4315 & 4315 & 4315 & 4315 & 4315 & 4315 \\
\hline \multicolumn{12}{|c|}{ Statistical Interpretation of Multiple Correlation Analyses } \\
\hline $\mathrm{INa}$ & \multicolumn{11}{|c|}{$\begin{array}{l}\text { At } 95 \% \text { confidence level, there were statistically significant and moderate correlations between INa } \\
\text { and (i) PL4 }(\mathrm{r}=.401, \mathrm{p}=.000) \text {. Additionally, there were statistically significant and weak } \\
\text { correlations between INa and (ii) PL1 ( } \mathrm{r}=.360, \mathrm{p}=.000) ;(\text { (iii) PL2 }(\mathrm{r}=.345, \mathrm{p}=.000) ;(\text { iv) PL3 (r } \\
=.356, \mathrm{p}=.000) ;(\mathrm{v}) \text { PL5 }(\mathrm{r}=.350, \mathrm{p}=.000) ;(\mathrm{vi}) \text { PL6 }(\mathrm{r}=.292, \mathrm{p}=.000) ;(\mathrm{vii}) \text { PL7 }(\mathrm{r}=.293, \mathrm{p}= \\
.000) ;(\text { viii) PL8 }(\mathrm{r}=.347, \mathrm{p}=.000) ; \text { (ix) PL9 }(\mathrm{r}=.365, \mathrm{p}=.000) \text {; and (x) PL10 }(\mathrm{r}=.394, \mathrm{p}=.000) \text {. }\end{array}$} \\
\hline $\mathrm{INb}$ & \multicolumn{11}{|c|}{$\begin{array}{l}\text { At } 95 \% \text { confidence level, there were statistically significant and weak correlations between INb and } \\
\text { (i) PL1 ( } \mathrm{r}=.321, \mathrm{p}=.000) ;(\text { ii) PL2 }(\mathrm{r}=.325, \mathrm{p}=.000) ;(\text { iii) PL3 }(\mathrm{r}=.343, \mathrm{p}=.000) ; \text { (iv) PL4 (r } \\
=.366, \mathrm{p}=.000) ;(\mathrm{v}) \text { PL5 }(\mathrm{r}=.349, \mathrm{p}=.000) ;(\mathrm{vi}) \text { PL6 }(\mathrm{r}=.314, \mathrm{p}=.000) ;(\mathrm{vii}) \text { PL7 }(\mathrm{r}=.323, \mathrm{p}= \\
.000) \text { (viii) PL8 }(\mathrm{r}=.372, \mathrm{p}=.000) ;(\mathrm{ix}) \text { PL9 }(\mathrm{r}=.357, \mathrm{p}=.000) \text {; and (x) PL10 }(\mathrm{r}=.337, \mathrm{p}=.000) \text {. }\end{array}$} \\
\hline $\mathrm{INc}$ & \multicolumn{11}{|c|}{$\begin{array}{l}\text { At 95\% confidence level, there were statistically significant and weak correlations between INc and } \\
\text { (i) PL1 ( } \mathrm{r}=.273, \mathrm{p}=.000) ;(\text { ii) PL2 }(\mathrm{r}=.268, \mathrm{p}=.000) ;(\text { iii) PL3 }(\mathrm{r}=.298, \mathrm{p}=.000) ; \text { (iv) PL4 (r } \\
=.323, \mathrm{p}=.000) ;(\mathrm{v}) \text { PL5 }(\mathrm{r}=.321, \mathrm{p}=.000) ;(\mathrm{vi}) \text { PL6 }(\mathrm{r}=.297, \mathrm{p}=.000) ;(\text { vii) PL7 }(\mathrm{r}=.312, \mathrm{p}= \\
.000) \text { (viii) PL8 }(\mathrm{r}=.342, \mathrm{p}=.000) ;(\mathrm{ix}) \text { PL9 }(\mathrm{r}=.326, \mathrm{p}=.000) \text {; and (x) PL10 }(\mathrm{r}=.318, \mathrm{p}=.000) \text {. }\end{array}$} \\
\hline
\end{tabular}

At $95 \%$ confidence level, there were statistically significant positive correlations between (i) INa and each of PL items, (ii) INb and each of PL items, and (iii) INc and each of PL items. The null hypotheses claiming there are no statistically significant correlations between (i) INa and respective PL items, (ii) $\mathrm{INb}$ and respective PL items, and (iii) INc and respective PL items were all rejected.

Three (3) multiple regression analyses were carried out to predict the values of each of dependent variables (i) $\mathrm{INa}$, (ii) $\mathrm{INb}$ and (iii) $\mathrm{INc}$ given the set of PL explanatory variables (PL1, PL2, PL3, PL4, PL5, PL6, PL7, PL8, PL9, and PL10). 
PLANNING MALAYSIA

Journal of the Malaysia Institute of Planners (2020)

Table 5 Multiple Linear Regression - PL predicting INa

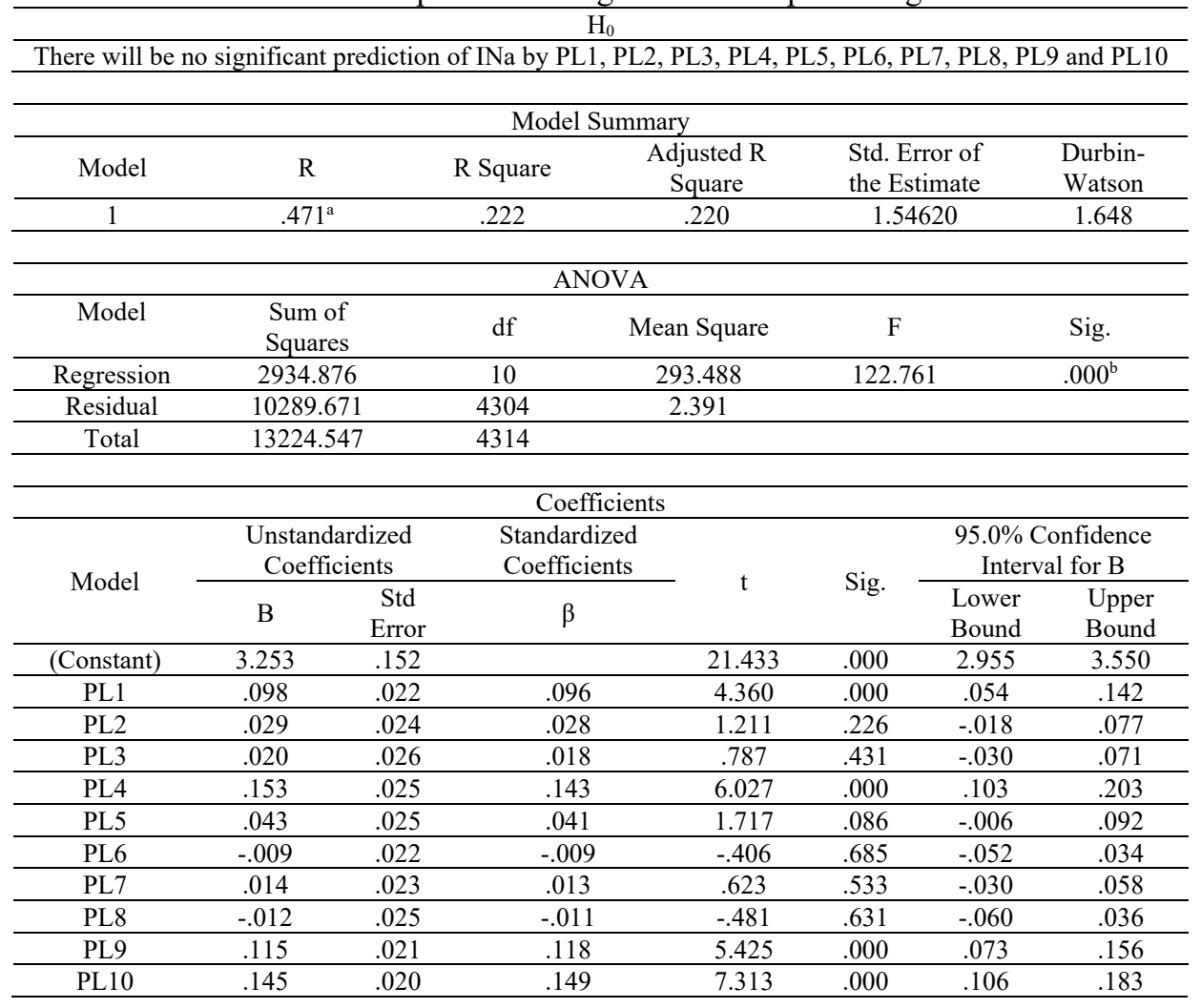

A multiple regression was generated to predict INa based on PL items. $\mathrm{R}$ value of .471 indicated adequate level of prediction $(\mathrm{R}>0.4)$. The DurbinWatson statistic was 1.648 which is greater than 1.0 and therefore the data was not autocorrelated. A significant regression equation was found, $\mathrm{F}(10,4304)=$ $122.761, \mathrm{p}=.000$, with an $\mathrm{R}^{2}$ of .222 ; indicating that the proportion of variance in INa that can be explained by PL items was $22.2 \%$.

At $95 \%$ confidence level, PL1 $(\mathrm{B}=.098, \mathrm{t}=4.36, \mathrm{p}=.000) ;$ PL4 $(\mathrm{B}=$ $.153, \mathrm{t}=6.027, \mathrm{p}=.000)$; PL9 $(\mathrm{B}=.115, \mathrm{t}=5.425, \mathrm{p}=.000)$; and PL10 $(\mathrm{B}=$ $.145, \mathrm{t}=7.313, \mathrm{p}=.000)$ were significant predictors of INa. On the contrary, it was found that PL2 $(\mathrm{B}=.029, \mathrm{t}=1.211, \mathrm{p}=.226)$; PL3 $(\mathrm{B}=.020, \mathrm{t}=.787, \mathrm{p}=$ $.431)$; PL5 $(\mathrm{B}=.043, \mathrm{t}=1.717, \mathrm{p}=.086) ;$ PL6 $(\mathrm{B}=-.009, \mathrm{t}=-.406, \mathrm{p}=.685)$; PL7 $(\mathrm{B}=.014, \mathrm{t}=.623, \mathrm{p}=.533)$ and PL8 $(\mathrm{B}=-.012, \mathrm{t}=-.481, \mathrm{p}=.631)$ were not significant predictors of INa.

Personality and Lifestyle (PL) items account for $22.2 \%$ of Nature Attachment (INa). Four (4) of PL items were significant predictors of INa. 
Aisyah Abu Bakar, Mariana Mohamed Osman \& Mizan Hitam

The Impact of Personality and Lifestyle on Interaction with Nature

Table 6 Multiple Linear Regression - PL predicting INb

\begin{tabular}{|c|c|c|c|c|c|c|c|}
\hline \multicolumn{8}{|c|}{ Model Summary } \\
\hline Model & \multicolumn{2}{|c|}{$\mathrm{R}$} & R Square & $\begin{array}{l}\text { Adjusted R } \\
\text { Square }\end{array}$ & \multicolumn{2}{|c|}{$\begin{array}{l}\text { Std. Error of } \\
\text { the Estimate }\end{array}$} & $\begin{array}{l}\text { Durbin- } \\
\text { Watson }\end{array}$ \\
\hline 1 & \multicolumn{2}{|c|}{$.445^{\mathrm{a}}$} & .198 & .196 & \multicolumn{2}{|c|}{1.44301} & 1.671 \\
\hline \multicolumn{8}{|c|}{ ANOVA } \\
\hline Model & \multicolumn{2}{|c|}{$\begin{array}{l}\text { Sum of } \\
\text { Squares }\end{array}$} & df & Mean Square & \multicolumn{2}{|c|}{$\mathrm{F}$} & Sig. \\
\hline Regression & \multicolumn{2}{|c|}{2210.859} & 10 & 221.086 & \multicolumn{2}{|c|}{106.176} & $.000^{\mathrm{b}}$ \\
\hline Residual & \multirow{2}{*}{\multicolumn{2}{|c|}{$\begin{array}{c}8962.079 \\
11172.937 \\
\end{array}$}} & 4304 & 2.082 & & & \\
\hline Total & & & 4314 & & & & \\
\hline \multirow{3}{*}{ Model } & & & ents & & & \\
\hline & \multicolumn{2}{|c|}{$\begin{array}{l}\text { Unstandardized } \\
\text { Coefficients }\end{array}$} & $\begin{array}{l}\text { Stand } \\
\text { Coef }\end{array}$ & \multirow{2}{*}{$\mathrm{t}$} & \multirow{2}{*}{ Sig. } & \multicolumn{2}{|c|}{$\begin{array}{c}95.0 \% \text { Confidence } \\
\text { Interval for B }\end{array}$} \\
\hline & B & Std Error & & & & $\begin{array}{l}\text { Lower } \\
\text { Bound }\end{array}$ & $\begin{array}{l}\text { Upper } \\
\text { Bound }\end{array}$ \\
\hline (Constant) & 3.188 & .142 & & 22.505 & .000 & 2.910 & 3.465 \\
\hline PL1 & .036 & .021 & & 1.721 & .085 & -.005 & .077 \\
\hline PL2 & .037 & .023 & & 1.652 & .099 & -.007 & .082 \\
\hline PL3 & .050 & .024 & & 2.054 & .040 & .002 & .097 \\
\hline PL4 & .083 & .024 & & 3.518 & .000 & .037 & .130 \\
\hline PL5 & 044 & .023 & & 1.895 & .058 & -.002 & .090 \\
\hline PL6 & .032 & .021 & & 1.542 & .123 & -.009 & .072 \\
\hline PL7 & .038 & .021 & & 1.785 & .074 & -.004 & . 079 \\
\hline PL8 & .093 & .023 & & 4.037 & .000 & .048 & .138 \\
\hline PL9 & .097 & .020 & & 4.916 & .000 & .058 & .136 \\
\hline PL10 & .033 & .018 & & 1.796 & .073 & -.003 & .069 \\
\hline
\end{tabular}

A multiple regression was generated to predict INb based on PL items. $R$ value of .445 indicated an adequate level of prediction $(R>0.4)$. The DurbinWatson statistic was 1.671 which is greater than 1.0 and therefore the data was not autocorrelated. A significant regression equation was found, $\mathrm{F}(10,4304)=$ $106.176, \mathrm{p}=.000$, with an $\mathrm{R}^{2}$ of .198; indicating that the proportion of variance in INb that can be explained by PL items was $19.8 \%$.

At $95 \%$ confidence level, PL3 ( $\mathrm{B}=.050, \mathrm{t}=2.054, \mathrm{p}=.040)$; PL4 (B $=.083, \mathrm{t}=3.518, \mathrm{p}=.000) ;$ PL8 $(\mathrm{B}=.093, \mathrm{t}=4.037, \mathrm{p}=.000)$ and PL9 $(\mathrm{B}=$ $.097, \mathrm{t}=4.916, \mathrm{p}=.000)$ were significant predictors of $\mathrm{INb}$. On the contrary, it was found that PL1 $(\mathrm{B}=.036, \mathrm{t}=1.721, \mathrm{p}=.085) ; \mathrm{PL} 2(\mathrm{~B}=.037, \mathrm{t}=1.652, \mathrm{p}=$ $.099)$; PL5 ( $\mathrm{B}=.044, \mathrm{t}=1.895, \mathrm{p}=.058) ;$ PL6 $(\mathrm{B}=.032, \mathrm{t}=1.542, \mathrm{p}=.123)$; PL7 $(\mathrm{B}=.038, \mathrm{t}=1.785, \mathrm{p}=.074)$ and PL10 $(\mathrm{B}=.033, \mathrm{t}=1.796, \mathrm{p}=.073)$ were not significant predictors of $\mathrm{INb}$.

Personality and Lifestyle (PL) items account for $19.8 \%$ of Knowledge and Capability (INb). Four (4) of PL items were significant predictors of INb. 
PLANNING MALAYSIA

Journal of the Malaysia Institute of Planners (2020)

Table 7 Multiple Linear Regression - PL predicting INC

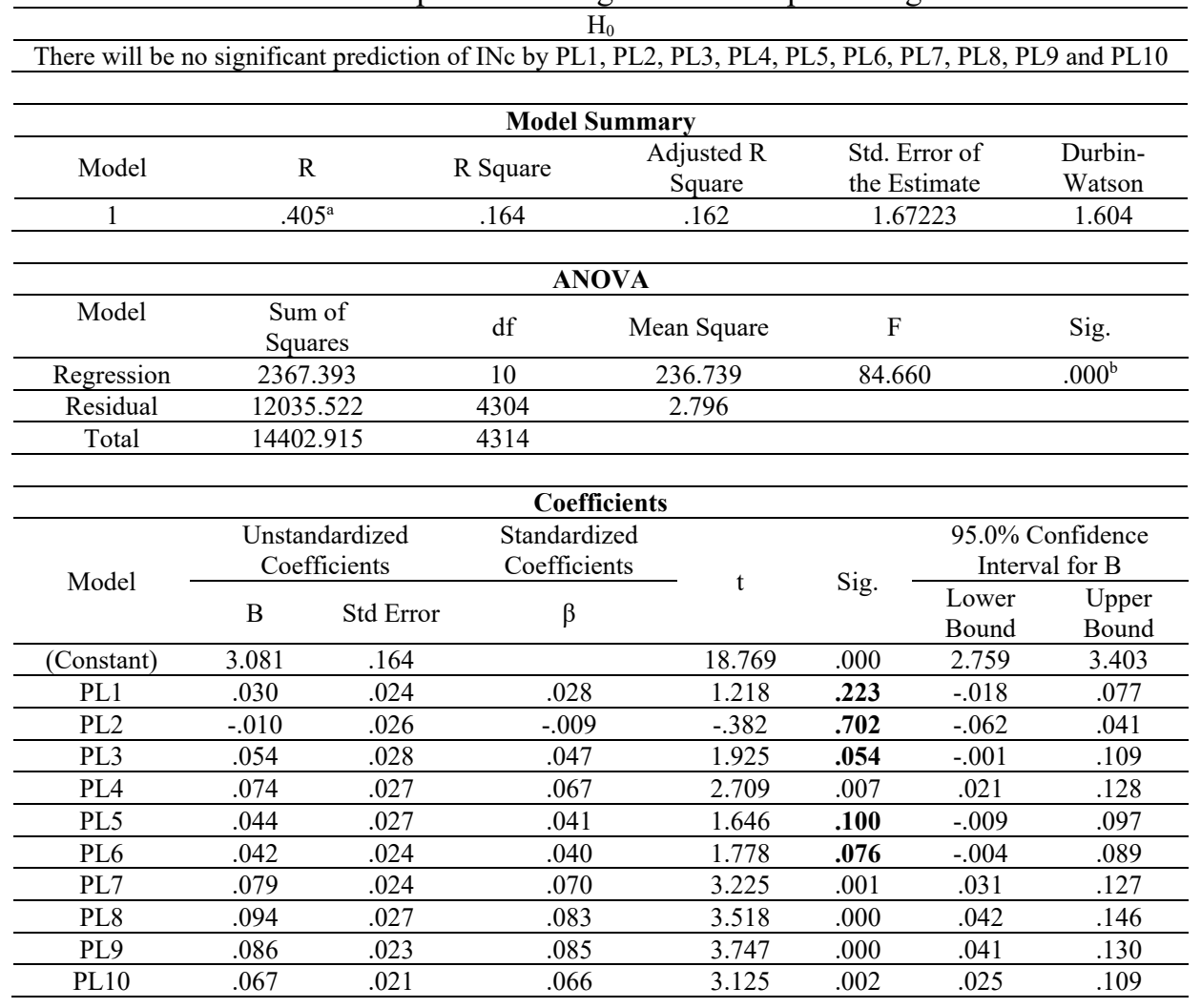

A multiple regression was generated to predict INa based on PL items. $R$ value of .405 indicated an adequate level of prediction $(R>0.4)$. The DurbinWatson statistic was 1.604 which is greater than 1.0 and therefore the data was not autocorrelated. A significant regression equation was found, $\mathrm{F}(10,4304)=$ $84.660, \mathrm{p}=.000$, with an $\mathrm{R}^{2}$ of .164; indicating that the proportion of variance in INc that can be explained by PL items was $16.4 \%$.

At $95 \%$ confidence level, PL4 ( $\mathrm{B}=.074, \mathrm{t}=2.709, \mathrm{p}=.007)$; PL7 (B $=.079, \mathrm{t}=3.225, \mathrm{p}=.001) ;$ PL8 $(\mathrm{B}=.094, \mathrm{t}=3.518, \mathrm{p}=.000) ;$ PL9 $(\mathrm{B}=.086, \mathrm{t}$ $=3.747, \mathrm{p}=.000)$ and PL10 $(\mathrm{B}=.067, \mathrm{t}=3.125, \mathrm{p}=.002)$ were significant predictors of INc. On the contrary, it was found that PL1 $(B=.030, t=1.218, p$ $=.223) ;$ PL2 $(\mathrm{B}=-.010, \mathrm{t}=-.382, \mathrm{p}=.702) ;$ PL3 $(\mathrm{B}=.054, \mathrm{t}=1.925, \mathrm{p}=.054)$; PL5 $(\mathrm{B}=.044, \mathrm{t}=1.646, \mathrm{p}=.100)$ and PL6 $(\mathrm{B}=.042, \mathrm{t}=1.778, \mathrm{p}=.076)$ were not significant predictors of INc.

Personality and Lifestyle (PL) items account for $16.4 \%$ of Collaborative Engagement (INc). Five (5) of PL items were significant predictors of INc. 
Aisyah Abu Bakar, Mariana Mohamed Osman \& Mizan Hitam

The Impact of Personality and Lifestyle on Interaction with Nature

Table 8 Summary of Findings

\begin{tabular}{|c|c|c|c|}
\hline & \multicolumn{3}{|c|}{ IV (Predictor Variables) - $\beta$} \\
\hline & PL2 & PL6 & PL10 \\
\hline \multirow{3}{*}{$\begin{array}{c}\text { DV } \\
\text { (Outcome } \\
\text { Variables) }\end{array}$} & $.096 \checkmark .028 \times .018 \times .1$ & $.143 \checkmark .041 X-.009 \times .013 \times-.011 X .118 \checkmark$ & $.149 \checkmark$ \\
\hline & $.039 \times .039 \times .049 \checkmark .0$ & $.085 \checkmark \quad .046 \times \quad .034 \times \quad .038 \times \quad .094 \checkmark \quad .109 \checkmark$ & $.037 X$ \\
\hline & $.028 \times-.009 \times .047 \times .0$ & 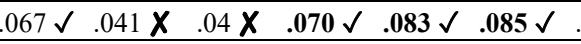 & $.066 \sqrt{ }$ \\
\hline & \multicolumn{3}{|c|}{$\checkmark=$ statistically significant predictor; $\boldsymbol{X}=$ not statistically significant predictor } \\
\hline DV & Indicators & Top 3 Strongest Predictors & $\beta$ \\
\hline \multirow{3}{*}{$\begin{array}{c}\text { INa } \\
\text { Nature } \\
\text { Attachment }\end{array}$} & \multirow{3}{*}{$\begin{array}{l}\text { - outdoor environment } \\
\text { determining own health and } \\
\text { wellness } \\
\text { - being able to recall experiences } \\
\text { in the natural environment }\end{array}$} & $\begin{array}{ll}\text { PL10 } & \begin{array}{l}\text { urging media to raise more } \\
\text { environmental awareness }\end{array}\end{array}$ & .149 \\
\hline & & PL4 $\begin{array}{l}\text { taking the pleasure of working with } \\
\text { others }\end{array}$ & .143 \\
\hline & & $\begin{array}{ll}\text { PL9 } & \begin{array}{l}\text { feeling affected by the environmental } \\
\text { loss of other countries }\end{array}\end{array}$ & .118 \\
\hline \multirow{3}{*}{$\begin{array}{l}\text { INb } \\
\text { Knowledge } \\
\text { and } \\
\text { Capability }\end{array}$} & \multirow{3}{*}{$\begin{array}{l}\text { - being able to adapt to various } \\
\text { outdoor surroundings } \\
\text { - being able to see and hear what } \\
\text { others usually miss in nature } \\
\text { - being able to notice scientific } \\
\text { details of nature } \\
\text { - being able to cope with the } \\
\text { outdoor environment }\end{array}$} & $\begin{array}{l}\text { PL9 feeling affected by the environmental } \\
\text { loss of other countries }\end{array}$ & .109 \\
\hline & & $\begin{array}{ll}\text { PL8 being mindful about environmental } \\
\text { destruction }\end{array}$ & .094 \\
\hline & & $\begin{array}{l}\text { PL4 taking the pleasure of working with } \\
\text { others }\end{array}$ & .085 \\
\hline \multirow{3}{*}{$\begin{array}{l}\text { INc } \\
\text { Inclination } \\
\text { towards } \\
\text { Nature }\end{array}$} & \multirow{3}{*}{$\begin{array}{l}\text { - feeling the urge to spend time in } \\
\text { the natural environment } \\
\text { - tending to lose concentration } \\
\text { without contact with nature } \\
\text { - tending to have objects from the } \\
\text { outdoors in personal space } \\
\text { - spending time planting at home }\end{array}$} & $\begin{array}{l}\text { PL9 feeling affected by the environmental } \\
\text { loss of other countries }\end{array}$ & .085 \\
\hline & & $\begin{array}{ll}\text { PL8 } & \begin{array}{l}\text { being mindful about environmental } \\
\text { destruction }\end{array}\end{array}$ & .083 \\
\hline & & $\begin{array}{l}\text { PL7 believing that having many assets does } \\
\text { not lead to happiness }\end{array}$ & .070 \\
\hline
\end{tabular}

The findings revealed that some of the PL items significantly account for INa, INb and INc. PL9, designating 'feeling affected by the environmental loss of other countries' was in the top three strongest predictors across IN components. The sense of moral responsibilities and concerns on global environmental problems implicitly and profoundly translate into emotions towards and aptitudes in the natural environment. Reaching out to people in different countries to inform on environmental issues are difficult due to language barriers, illiteracy and cultural differences. Local outreach, media outlets and classroom education can ease the communication barriers, spread messages and foster sense of proactive citizenships hence deepen shared empathy towards the natural surroundings.

\section{CONCLUSION}

HIE in SSWB promotes the idea the ways humans interact with nature originates from their collectivist backgrounds and biospheric values. This paper evidence that IN is predictable through PL. Statistical modelling on the constructs elaborated in this paper is warranted for future research. 
PLANNING MALAYSIA

Journal of the Malaysia Institute of Planners (2020)

\section{ACKNOWLEDGEMENT}

This research was supported by Post-Doctoral Fellow under Research Initatives Grant Scheme (RIGS-PDF), International Islamic University Malaysia (project title: RPDF19-005-0015)

\section{REFERENCES}

Abu Bakar, A., Mohamed Osman, M., Bachok, M., Hitam, M., and Abdullah, A. (2018). Human Interdependency for Sustainable Well-Being: Structural Invariance across Settlement Areas. Planning Malaysia: Journal of the Malaysian Institute of Planners. 16(1) pp. 281-293.

Abu Bakar, A., Mohamed Osman, M., Bachok, S., Ibrahim, M., Abdullah, A., and Abdullah, F. (2017a). A Review on Sustainable Wellbeing Indicators for Human Interrelationships with the Environment. Planning Malaysia: Journal of the Malaysian Institute of Planners, 15 (1). pp. 357-368. ISSN 1675-6215.

Abu Bakar, A., Mohamed Osman, M., Bachok, S., Ibrahim, M., Abdullah, A., and Abdullah, F. (2017b). A theoretical assessment on sustainable wellbeing indicators for people interrelationships. Planning Malaysia: Journal of the Malaysian Institute of Planners, pp. 21-30. ISSN 1675-6215.

Abu Bakar, A., Mohamed Osman, M., Bachok, S., Ibrahim, M., and Abdullah, A. (2017c). Sustainable Well-Being: An Empirical Exploration on Human Interdependence with the Environment. Advanced Science Letters. American Scientific Publishers. 23(7) pp. 6352-6356.

Caesar, L. A. Y. (2016). Performance Excellence by Transformational Leadership in Developing Collectivistic Culture for Indonesian Companies. Pertanika Journal of Social Sciences and Humanities, 24(May), 19-32.

Clark, M., Amar-Singh, H. S., \& Hashim, L. (2014). The Subjective Well-Being of Malaysian School Children: Grade Level, Gender and Ethnicity. Psychology, 5(5), 1453-1462.

Dancey, C. and Reidy, J. (2004) Statistics without Maths for Psychology: using SPSS for Windows. Prentice Hall, London.

Faizi, M., Azaria, a K., \& Maleki, S. N. (2013). Design Guidelines of Residential Environments to Stimulate Children's Creativity. Journal of Asian Behavioural Studies, 3(February 2013), 25-36.

Ghazali, R., \& Abbas, M. Y. (2011). Paediatric Wards: Healing environment assessment. Asian Journal of Environment-Behaviour Studies, 2(January 2011), 63-75.

Horayangkura, V. (2012). Incorporating Environment-Behavior Knowledge into the Design Process: An Elusive Challenge for Architects in the 21st Century. Procedia - Social and Behavioral Sciences, 50(July 2012), 30-41.

Inani, D. I., Abdul Karim, H., \& Mohd Amin, M. Z. (2013). Walking Behavior of Urban and Rural Streets. Journal of Asian Behavioral Studies, 11(July 2013), 97-110.

Khare, A. (2015). Influence of Materialism and Money Attitudes on Credit Card Use. International Business Competition and Growth, 4(2), 57-77.

Khotdee, M., Singhirunnusorn, W., \& Sahachaisaeree, N. (2012). Effects of Green Open Space on Social Health and Behaviour of Urban Residents: A Case Study of 
Aisyah Abu Bakar, Mariana Mohamed Osman \& Mizan Hitam

The Impact of Personality and Lifestyle on Interaction with Nature

Communities in Bangkok. Procedia - Social and Behavioral Sciences, 36, 449 455.

Laurens, J. M. (2012). Intervention Program to Change the Pro-environmental Behavior of the Riverside Community. Journal of ASIAN Behavioural Studies, 2(January 2012), 45-56.

Mahidin, A. M. M., \& Maulan, S. (2012). Understanding Children Preferences of Natural Environment as a Start for Environmental Sustainability. Procedia - Social and Behavioral Sciences, 38(December 2010), 324-333.

Mansor, M., Said, I., \& Mohamad, I. (2012). Experiential Contacts with Green Infrastructure's Diversity and Well-being of Urban Community. Asian Journal of Environment-Behaviour Studies, 49(May 2010), 33-48.

Maruthaveeran, S. (2012). The Perception of Social Safety in a Green Environment: A Preliminary Study at the Kepong Metropolitan Park. Journal of Asian Behavioral Studies, 1(January 2010), 45-56.

Ming, B. H., Gan, G. G. G., \& Ramasamy, S. (2015). The Role of Concern for the Environment and Perceived Consumer Effectiveness on Investors' Willingness to Invest in Environmental-Friendly Firms. Kajian Malaysia, 33(1), 173-190.

Ngesan, M. R., Karim, H. A., \& Zubir, S. S. (2013). Human Behaviour and Activities in Relation to Shah Alam Urban Park during Nighttime. Asian Journal of Environment-Behaviour Studies, 4 (October 2013).

Shukur, F., Othman, N., \& Nawawi, A. H. (2011). The Values of Parks to the House Residents. Asian Journal of Environment-Behaviour Studies, 1(5), 85-94.

Zainol, R., Nordin, N. A., Sandri, D., \& Ahmad, F. (2012). Nature Seekers within the Urban Vicinity. Joruanl of Surveying, COnstruction and Property, 3(2), 1-13. 